\title{
Fate across Cultures: a Linguocognitive Approach
}

\author{
Mara Baghdasaryan \\ Yerevan State University
}

\begin{abstract}
Concepts may have different conceptual-semantic coverage and lexical realization in different cultures and languages. In the present paper a cognitive framework has been elaborated to look into the concept fate across different linguocultures - Armenian, Russian, English and Italian, and to reveal its culture bound characteristics along with its universal essence, that is reveal fate in linguocultural thinking.
\end{abstract}

Key words: concept fate, linguoculture, linguocultural thinking, cognitive frame, conceptualization, lexical and semantic realization, phraseological unit.

\section{Introduction}

Expressions, sentences and even whole texts can often be incomprehensible even in case of the knowledge of words and grammar forms. Such a situation occurs because of the lack of cultural knowledge. There are concepts that represent "whole worlds" which need to be revealed. Different nations, naturally, have a different history, language, way of communication, lifestyle, perception of the world - in a word, a different culture.

Language encompasses and transfers huge cultural information - what national characteristics the nation has, in what geographical and social conditions it lives, what traditional food it eats, what developed fields of activity it has, what view and perception of the world it demonstrates, what it says to itself and the world, and how it says it.

Language with all its means is understood in the context of communication, and context finds its realization or specification in culture. In other words, language is a reflection of concepts and meanings which differ 
from culture to culture. In specific languages the cultural semantics of concepts is a powerful condensation of traditional practice and values. This is the reason why certain words or names of phenomena have different moral, intellectual, conversational and practical meanings in different languages, and their lexical counterparts are often not identical in other languages.

\section{Fate in the Armenian and Other Linguocultures:}

\section{Definitions and Lexical Realizations}

The concept to be presented in this paper is fate (puifun). What is the concept fate? In what way do we use it? And what are our expectations from it? These, actually, are not very easy questions to answer. Surely, fate is a universal concept probably existing in all languages as it is inherent to human thinking and life. But this does not mean that our ideas and expectations related to fate are identical. Here is where culture comes to have a key role, and the linguistic expression - its variety and shades of meaning are representative of culture. The idea of fate is traditionally and firmly entrenched in an Armenian's worldview. It is so usual for Armenians that often in speech without any specific contemplation, as if automatically, they may say, for example, fuifunh puis $h$ (it's a matter of fortune'), Uupn Furhun uhpun nziliuu (one should have a

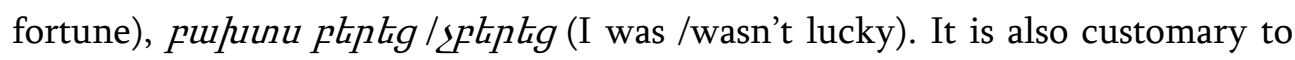
express good wishes to young people, in particular words wishing a happy

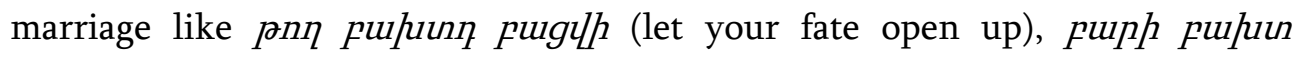
nulitivuu (have a good fate) are said to unmarried young ladies. Another good wish to young ladies is the phrase handed down to us from our grandmothers -

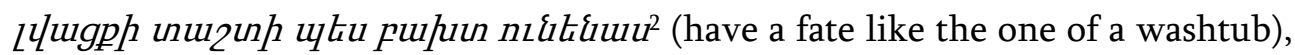
meaning good fortune, luck and abundance, for as we know, the washtub hardly ever gets empty. Marriage and family happiness have always been crucial in the Armenian mentality and lifestyle and, naturally, have found their way into language. Hence the concept fate could not have circumvented such a key field of the Armenian culture as marriage and family. This will be discussed in more detail and in comparison to other linguocultures further in the paper. 
In our reference to the concept fate we would like to focus on phraseological units as these language realizations are usually typical cultural condensations and provide a wide spectrum of the meaning of a concept and its functioning in a specific culture. The phraseological units with the concept fate are mainly represented by the word purfun and in a few cases by the word বuluшишqhp in Armenian. In Russian its lexical realizations are судьба and рок, the latter having solely a negative meaning. In English the most semantically comprehensive word representing this concept is fate. Though it should be mentioned that in English and Italian the conceptual-semantic realization of this concept is more disperse and the latter is usually verbalized in phraseological units through the lexical units fate, fortune, luck, destiny in English and fortuna, fato, destino, sorte in Italian. Anyway, fate, fortune in English and fato, fortuna in Italian are more generally representative of the concept fate.

Before starting the examination of the phraseological units with the concept fate we would like to present the definitions given by dictionaries to its main or comparably more comprehensive lexical expressions in the four languages under discussion (the presentation of the specifically professional or technical realizations of the concept are omitted here as non-relevant to this research).

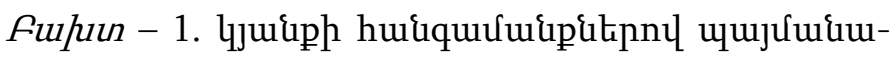

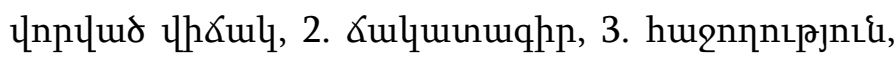

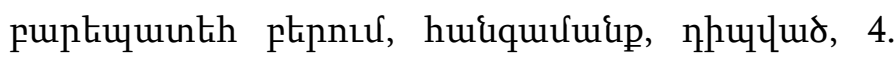

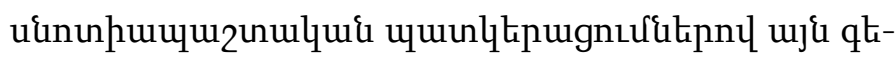

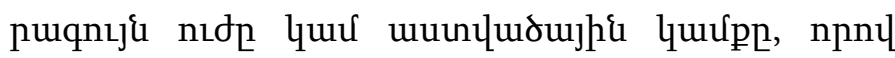

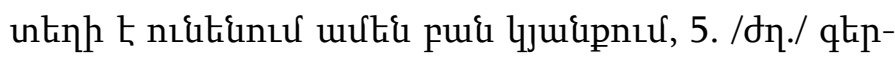

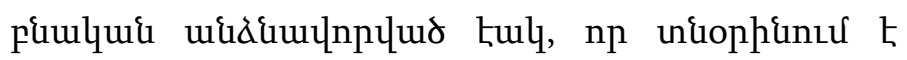
uupnlquigg ljuipp (Uпujuí 1976):

Судьба - стечение обстоятельств, не зависящих от воли человека, ход жизненных событий, 2. доля, 
участь, 3. история существования кого-, чегонибудь (кн.), 4. будущее, то, что случится, произойдет (Ожегов 1988).

Fate - 1. the development of events outside a person's control, regarded as predetermined by a supernatural power; the course of someone's life, or the outcome of a situation for someone or something, seen as outside their control; the inescapable death of a person (Oxford Dictionary 2010).

Fortune - 1. chance or luck as an arbitrary force affecting human affairs; luck, especially good luck; (fortunes) the success or failure of a person or enterprise over a period of time, 2. a large amount of money or assets; (a fortune) a surprisingly high price or amount of money (Oxford Dictionary 2010).

Fortuna - 1. destino o sorte alterna, indipendente dalla volontà umana, identificata dagli antichi nell'omonima divinità (la dea bendata) distributrice a caso di gioia e dolori, 2. sorte favorevole, destino propizio, 3. averi, patrimonio, ricchezza; /lett./ condizione economica o sociale, 4. /lett./ sorte o destino avverso, vicenda disgraziata, 5. rompicollo (Zingarelli 2014).

Fato - 1. per gli antichi, legge eterna e ineluttabile che regola e domina senza contrasto la vita dell'Universo, 2. destino, caso, fatalità (Zingarelli 2014).

As is evident from the dictionary data the given concept largely means chance as an arbitrary force affecting human affairs, success, development of events outside a person's control and regarded as predetermined or regulated by a supernatural power, as an outcome of a situation, the course of one's life, as well as economic welfare.

\section{The Phraseology of Fate through Cognitive Modelling}

With reference to phraseological units it should be stated that even at a very first sight it is obvious that the Armenian phraseological units with the concept fate are incomparably more numerous, and the Armenian wordconcept fuluun is more comprehensive. In phraseological dictionaries 
(Unıphuujui, quuuunuui 1975, Войнова, Жуков, Молотков, Федоров 1986, Oxford Dictionary of Idioms 2004, Zingarelli 2014) there are more than 100 Armenian, around 5 Russian, 15 English and 35 Italian phraseological units with this concept. According to the language data provided by the dictionaries a set of frames $3 /$ mental models, i.e. a cognitive framework of the concept fate has been elaborated in the course of the present research aimed at revealing linguocultural thinking. Thus fate is presented through the following cognitive frames and subframes.

1. fate - success/chance

1.1. personified success/chance

1.2. success in socio-economic perspective

2. fate - marital happiness/success

3.1. fate - destiny - future

3.1. future/end

3.2. fate - destiny-life

4. incident, event (negative)

4.1. fateful incident

4.2. haphazard event

5. fate - money (usually in a large amount)

Our examination of the phraseological units with the concept fate has shown that in the Armenian culture there is a strong disposition to fate or in other words it is fate-centered (pupuunulfiunnni) to a considerable extent. Success is considered crucial in all the domains of human activity and the idea of success finds its linguocultural realization in a variety of contexts. A very typical characteristic of success is chance, and not only in the Armenian linguoculture as the linguistic evidence shows. So the first cognitive frame is fate - success/chance. The idea of chance and unexpectedness is present in many phrases and it can often be positive as well as negative resulting in the 
attainment or loss of success or else having good or bad luck: pupunn ptipt $\mathrm{L}=$

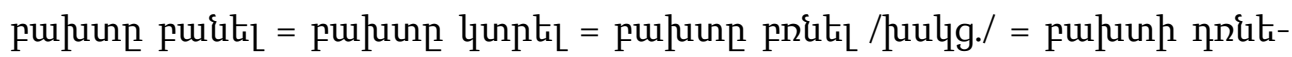

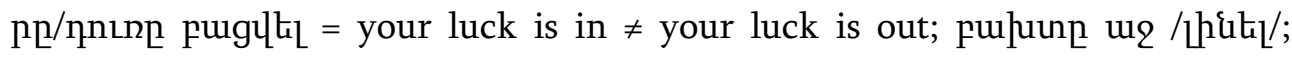

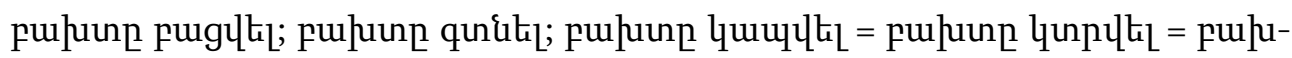

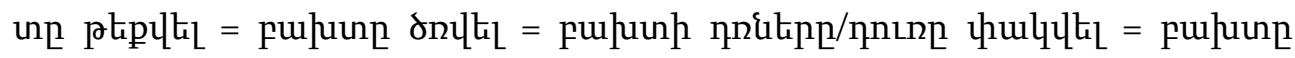

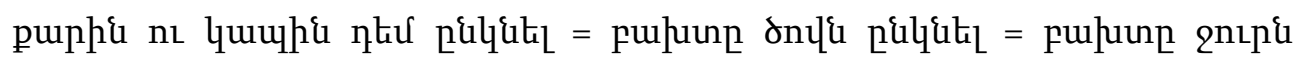

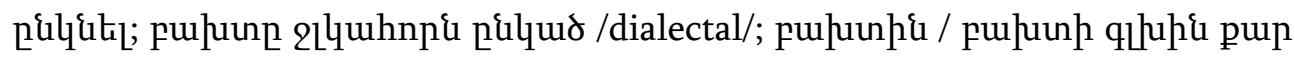
qgki /punnl unul/, pugh/pugnl unul hp/ftilh puhunhs = pupunh wnuq

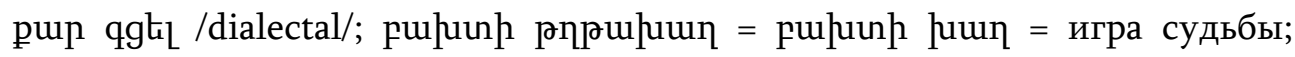
puluunfi pnnquil = [оставить $]$ на произвол судьбы = abbandonare qlcu. al proprio destino $=$ abbandonare qlcu. alla sua sorte; puuunhi unul $/ \mathrm{hpti} /=$ affidarsi alla fortuna = affidarsi/rimettersi alla sorte; puhuunh puí $\mathrm{h} /$ huulg./ = è solo questione di fortuna; puhunh phpuuufp/pthunntupnl = as luck would have it = è destino /che/; puluun

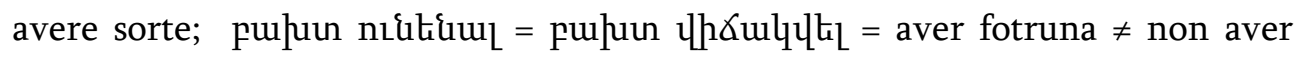

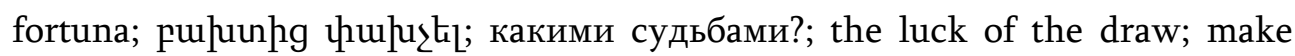
your own luck; ride your luck; ha tutte le fortune; avere/toccare in sorte; un colpo di fortuna, portar fortuna, fare la fortuna di qlcu., mezzi di fortuna.

The phrases with the concept fate can have unique lexical and semantic realizations such as in the Armenian linguoculture pupunn pulqutu, puluun

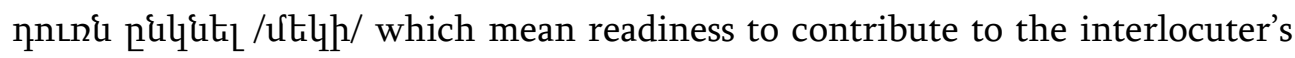
success in any way asking for help in a difficult or desperate situation. Another unique linguistic expression is Armenian pupunn uhptur which is an exclamation of admiration with reference to a person who is always lucky. In the Armenian phrases it is usual to come across the word puluu with the possessive ending or a possessive pronoun like puhun $u / h U$ pulunn, puluun $\eta$ /

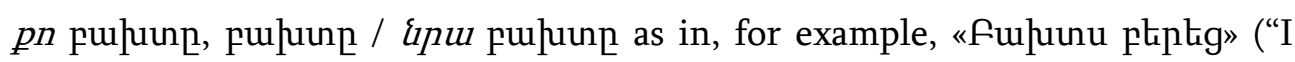
was lucky enough”). Among the Armenian phrases there are also derivatives

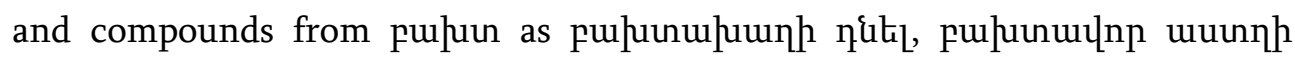

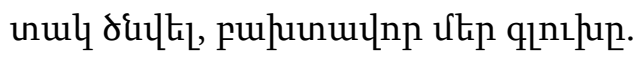

It is also noteworthy to observe how duluunuq $h p$ - another realization of the concept fate in Armenian - is expressed in phraseological contexts. The 
compound word đurquunuqhp, i.e. a writing on the forehead - a person's destiny predetermined for him, is split into its components Gulyuun (forehead) and $q h p$ (writing) and is used to make phraseological units with syntactic

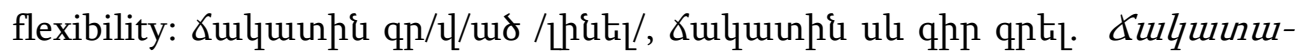
$q h p$, as is clear, indicates a necessarily predetermined course of events.

An interesting lexical-syntactic unit is the typically Russian phrase какими судьбами? which is actually a question having a specific contextual functioning. In English there is an interesting phraseological unit with the word lucky derived from luck - you, he, etc. will be lucky (or should be so lucky) which is a predicative syntactic unit, actually a sentence and is "used to say that someone's wishes or expectations are unlikely to be fulfilled" [Siefring 2004]. It is an ironic phrase expressing just the contrary - the absence or the impossibility of the luck. A similar case comes across among the Armenian

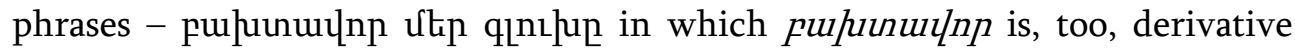
from puluun, and is synonymous to lucky. The phrase literally means lucky (is) our head but the phraseological meaning is the contrary - we are not lucky (enough for). It is a colloquial phrase which is notably emotionally saturated.

A remarkable fact about fate as success/chance is that it is often personified. So we distinguish a subrame fate - personified success/chance. The concept of fate as success/chance is endowed with characteristics typical of a human being. Often in the Armenian linguoculture these phrases even exist in antonymic pairs indicating that fate, like a human being, can possess characteristics of the opposite directions. Thus, in Armenian:

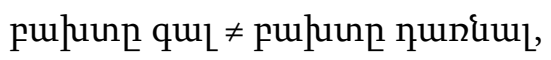

puruing tiun quil,

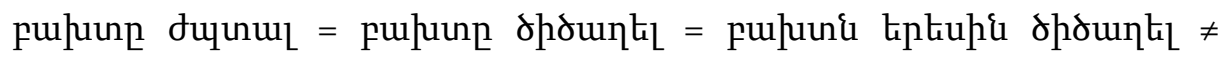

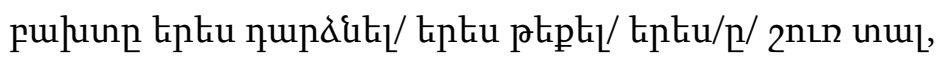

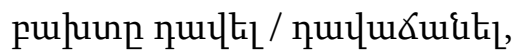

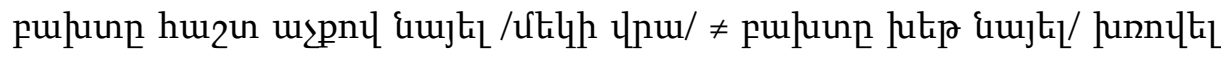
/utilyg/,

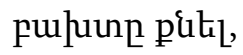

puluunn pnnugiti, 


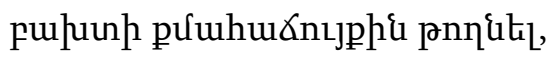

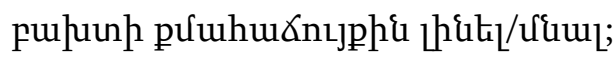

in Russian

волею судьбы,

ирония судьбы,

искушать судьбу;

in English

tempt fate,

fortune favours the brave;

in Italian

tentare la fortuna = tentare la sorte,

ai capricci della fortuna,

figlio della fortuna,

ha una fortuna sfacciata, rassegnarsi al destino = subire al destino,

essere perseguitato dal destino,

essere in balia della sorte,

opporsi al fato.

It is evident that such actions as come (qui), go back (nunquul), come back

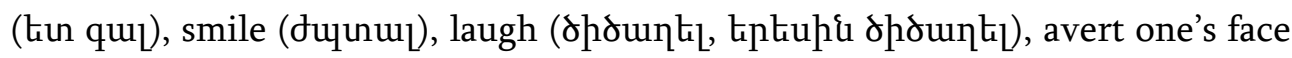

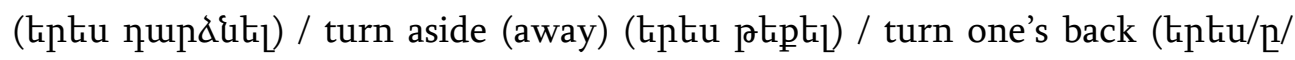

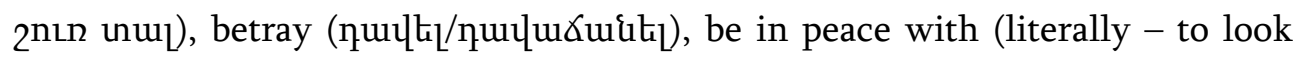

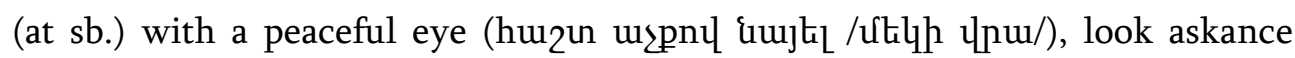

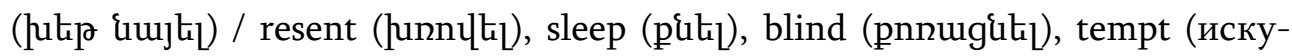
шать, tentare), favour, submit (rassegnarsi, subire), be pursued (essere perseguitato), be under sb's control (essere in balia di qlcu.), oppose (opporsi) indicate relations between humans, as well as such characteristics as whim/caprice (pưhưrnıјp, capriccio), will (воля), irony (ирония), impudence (sfacciato - impudent, shameless) and figlio (child) normally pertain 
to humans. The language material shows that the personification takes particularly various lexical forms and finds a whole range of semantic, contextual realizations in the Armenian and Italian linguocultures.

The other subframe distinguished within the frame fate - success/chance presents fate as success in socio-economic perspective. This type of success is observed separately as there are several phraseological units which specifically

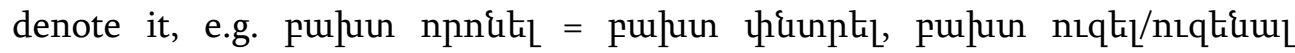
(partially), as distinct from the bulk of the phraseological units which denote success/chance in general. But it should be noted that the specific meaning of socio-economic well-being is presented in the Armenian dictionary by this small number of phrases only, which can be representative of culture, indicating that success in the social and economic domain does not have a central role in the understanding of fate being success in the Armenian culture.

The situation is completely different with another realization of fate as marital happiness-success. The latter has an important part within the conceptual field of fate in the Armenian culture and specifically with reference to ladies as further will be demonstrated on examples:

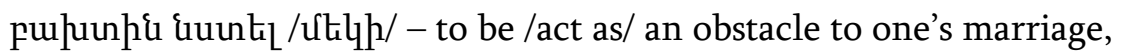

puluun humpt $\mathrm{L}_{\mathrm{L}}$ - to ask for love, welfare,

puhuuntpupun palqukl (dialectal - about a widow or a widower) - to get married several times (literally - to fall from fate to fate),

puhunn pugl $\mathrm{t}_{\mathrm{L}}$ - (2nd meaning) a lady has married (literally - fate opens up) $\neq$

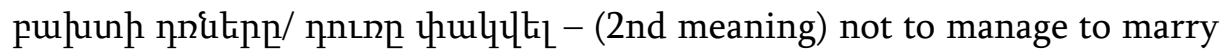
for a long time (mainly about ladies) (literally - the doors of fate close),

pupunp nnınp puiuu - to marry a lady off (literally - to open the door of fate) $\neq$

puruunp pnnugitil (colloquial) - to make unfortunate, wreck the future (generally about a lady who is not getting married) (literally - to blind the fate),

puruunp luuu $\vdash$ - no one proposes to a lady (literally - the fate is tied up),

puhunn quuuk (colloquial, superstitious) - (2nd meaning) to act as an obstacle to a lady's marriage (literally - to tie up the fate), 
puluun nuph2 untn hiunptl/ hiunphp (colloquial) - to propose to a lady from another place; also in the form of an order used as a reply to the matchmaker (literally - to look (look!) for the fate in another place).

In the dictionary definitions of the first three phraseological units there is no special reference to ladies but the statements exemplifying the first two refer to ladies. The third one is exemplified by statements referring to both men and women. It is notable that it has an intensified semantics of the idea of fate. This is due to the double use of puluu (fate) within the word puluuntipulun, making the phrase emotionally more coloured and intensive which is quite usual with dialectal and colloquial phraseological units. The next six phrases are even defined with immediate reference to ladies. Language as the reflection of the culture clearly shows the relationship between marriage and fate, or more specifically the role of fate in marital happiness/success, family being the generally accepted form of personal happiness in the Armenian world. Particularly ladies' marital happiness / success has traditionally been fate bound and they are usually wished puph purfun (good fate) in the patriarchal Armenian society where a man is expected to propose to a lady and take her to his home after marriage. This is the reason why there is such a phraseological unit in the Armenian linguoculture as unum ufuul (literally - to stay/remain at home) which means the lady is unmarried or her success in marital happiness has not opened up to her (puluunp puglt $\mathrm{L}_{\mathrm{L}}$ - fate opens up). It is also

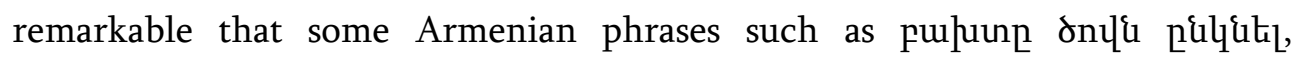

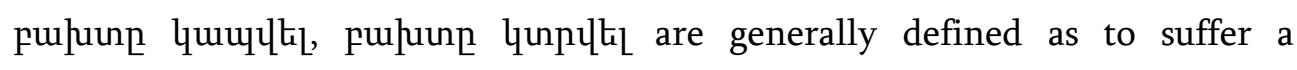
misfortune but the illustrations, which are predominantly from fiction, all make a reference to the lady's marital issue. The final phraseological unit on this list, puhuun nıph2 untn hiunpl l/ hiunnhn, pertains to men specifically and can be a refusal (also in the form of an imperative statement) to a man proposing to a lady. So, this comes to assert that in the traditional Armenian society a man makes a proposal to a lady which in its turn, still, needs to be accepted by her and/or her parents.

The third major frame elaborated within the present research can be presented as follows: fate - destiny-future and fate - destiny-life in which the 
concept fate is realized as human destiny actualized in the idea of the future and in the idea of life, respectively. These are two parallel conceptualizations of fate none of them being a subframe of the other. Many of the phrases belonging to the first group are connected to the superstitious idea of foreseeing the future,

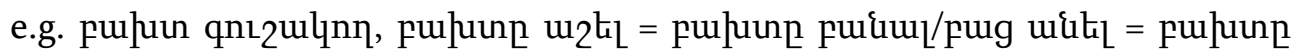
$q \mathrm{k}_{\mathrm{L}}=$ puluun quuj $_{\mathrm{k}}=$ predire/leggere il destino a qlcu. Others express the idea of the future destiny in different contextual-phraseological realizations:

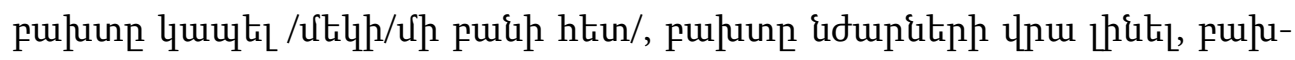

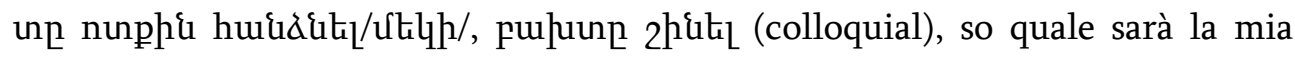
sorte. Among the English phraseological units there is also a phrase seal someone's fate which means "make it inevitable that something unpleasant will happen to someone" (Oxford Dictionary of Idioms 2004). Here, too, there is a direct reference to fate as destiny-future. This phrase has some similarity to the Armenian phrase pupunn quuli (literally - to tie up the fate) which is colloquial and has the superstitious meaning of bringing bad luck by spell.

It is interesting that there is a subtle variation to the realization of fate as

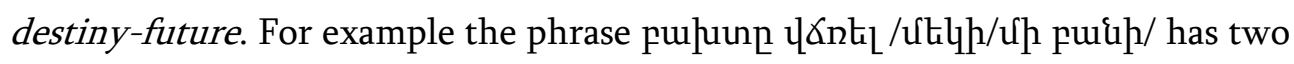
meanings: the first one is to take a crucial decision on an important question and is synonymous to decidere della sorte di qlcu., and the second one is to have a decisive influence on the result of something. So in the latter case the frame is a little modified to fate-destiny - future/end.

The realization of fate as destiny-life can be exemplified through such

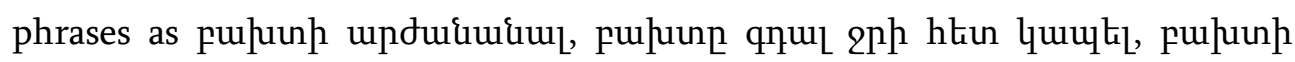

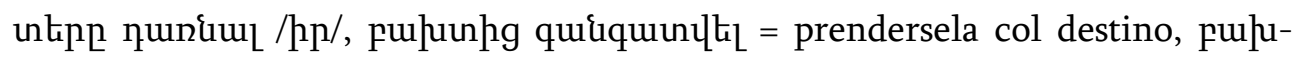

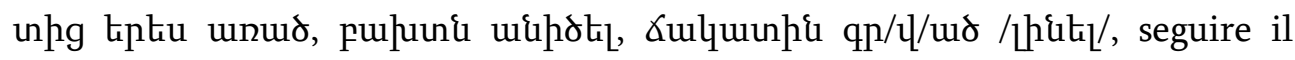
proprio destino, cedere al fato and also a group of phrases with the metaphoric expression puluun wifhl (the wheel of fate) usually with reference to the different directions life takes: puluun $\mathrm{w}$ uhl = la ruota della fortuna, puuun

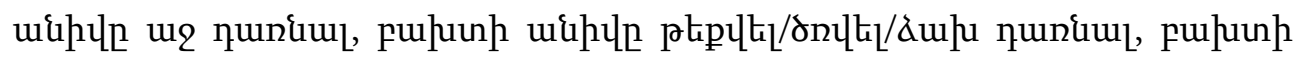

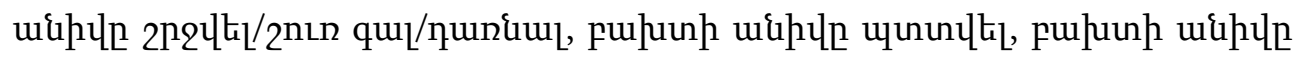
Ł2nıр-ц2nıp hitil. 
A special focus should be given to the phrases pupun nultikul $=$ aver fortuna meaning to be successful and pupun nLftituul = avere sorte meaning to have a good life. The phrase puluun nufituul is very popular in the Armenian linguoculture and can obviously be referred to both frames fate success/chance and fate-destiny-life.

There are also two minor frames presented on our list to show how else the concept fate works. In the English linguoculture one of them conceptualizes fate as a negative incident, event - either a fateful incident or an unpredictable, haphazard event: a fate worse than death (a terrible experience, especially that of seduction or rape), the fortunes of war (the unpredictable events of war).

The other conceptualization of fate is the idea of money, usually in a large amount. in English the informal phrase a small fortune expresses the idea of a large amount of money in a playful manner, or the phrase a soldier of fortune is used to denote a person ready to take a service under any person or state in return for money, in Italian the phrase fare fortuna means to become rich like in English the phrase make a fortune, also in Italian the phrases cadere in bassa fortuna and trovarsi in bassa fortuna are literary expressions meaning go bankrupt/be bankrupt in which fortuna, i.e. fate actualizes the idea of economic, financial welfare. This kind of specific realization of the concept under discussion is not found in the Armenian or Russian linguocultures. It is typical of the English and Italian linguocultures. The English word fortune and the Italian word fortuna on their own have the meaning of wealth, capital among other meanings. Whereas with general reference to socio-economic welfare, as already stated in this paper, in Armenian we only come across the phrases pupun npniti = puruun hiunpt (literally - to look for fate), pupun

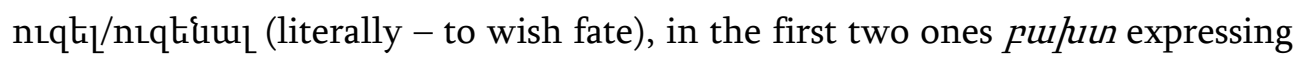
the idea of means of living, in the third one also happiness in general.

Finally, we would like to focus on a specific conceptual condensation - the phrase hujh puupun (the Armenian's fate) used in spoken Armenian. It means bad luck, unhappiness. This phrase has become widely circulated in the recent century and is largely connected with the Armenian Genocide of 1915. But there is a remarkable fact - this phrase has not found its way into dictionaries, 
that is it has not "found its place" in standard Armenian. This means that notwithstanding the many atrocities, namely the genocide the Armenian people went through and survived, this nation, though preserving the memory on the genetic level, does not believe they are a nation with a victim's soul and mind, but does believe they are a nation with a survivor's soul and mind looking to the future. So the Armenian nation has preserved this phrase on the level of Saussurean parole and does not adopt it into their language on the level of Saussurean langue.

\section{Conclusion}

Fate is a vital concept in human thinking and active in all the languages we have looked into in the framework of this research. Fate is a universal concept with universal essence as man is not endowed to reach the essence of all existence. Fate is something we are born with, live with, rely on, look for, discover and create. Despite its universal characteristics the concept fate also has unique or more typical characteristics conditioned by different culture bound factors and deeply rooted in national linguocultures.

As the present research has shown the concept fate is most widely referred to in the Armenian linguocultur, and the reference fields are success/chance including personified success/chance, marital happiness/success, destiny-future and destiny-life (the vast number of phraseological units often with a variety of synonyms and antonyms provide us with a profound evidence). This concept is also considerably active in the above mentioned fields excluding the one of marital happiness/success in the Italian linguoculture.

The role of fate is unique in marital happiness in the Armenian culture as distinct from all the other cultures, at least the ones under discussion. And specifically ladies are found to be in the realm of fate.

Another typical realization of the concept fate/fortune is the idea of economic, financial welfare, but in this case typical of the English and Italian linguocultures as distinct from the Armenian and Russian ones. The analyzed linguistic data can also lead to the idea that this kind of actualization of fate is typical of European cultures in general. 
Surely, the topic of the present research is far wider and can give much more food for thought but the cognitive research of the phraseological units can already provide a deep insight into the linguocultures and linguocultural thinking.

\section{Notes:}

1. The English translations of the Armenian phraseological units in this paper have been done by the author (M. B.).

2. It is remarkable that in Armenian there are phrases with the concept fate (puifun) such as puph pupun /ntqukiul/, lumgph unuzunh uliu pupun nutukuul which are widely used in the spoken language but are not recorded in dictionaries and are actually used by force of tradition.

3. A frame can be defined as a structure of knowledge or a mechanism of knowledge building: in the broad sense, a frame is a cognitive model. A frame is a unified structure of knowledge, a coherent schematization of experience. It is a structure of data which exists in a person's consciousness and which a person uses to recognize and process typical situations and phenomena. It represents the essential, typical and possible features of the concept, which can be conditioned to this or that extent, that is they have a situational basis. Frames shape a person's perception of the world and direct their behaviour (Cf. Kubryakova, Dem'yankow, Pankrats, Luzina 1997, Minskij 1979, Fillmore 1988).

\section{References:}

1. Aghayan, E. (1976) Ardi hayereni batsatrakan bararan. Yerevan: "Hayastan" hratarakchutyun.

2. Sukiasyan, A.; Galstyan, S. (1975) Hayots lezvi dardzvatzabanakan bararan. Yerevan: Yerevani hamalsarani hratarakchutyun.

3. Voynova, L.; Zhukov, V.; Molotkov, A.; Fyodorov, A. (1986) Frazeologicheskiy slovar' russkogo yazika. / Pod red. A. Molotkova, Izd. 4oye. M.: Russkiy yazik. 
4. Kubryakova, Ye.; Demyankov, V.; Pankrats, Yu.; Luzina, L. (1997) Kratkiy slovar' kognitivnikh terminov. M.: MGU.

5. Minskiy, M. (1979) Freymi dlya predstavleniya znaniy. M.: Energiya.

6. Ozhegov, S. (1988) Slovar' russkogo yazika. 20-oye izd. M.: Russkiy yazik.

7. Fillmore, Ch. (1988) Freymi i semantika ponimaniya. // Novoye v zarubezhnoy lingvistike. Kognitivniye aspekti yazika. Vip. XXIII. M.: Progress.

8. (2010) Oxford Dictionary (for ABBYY Lingvo x5). 3rd ed.. Oxford: OUP.

9. (2004) Oxford Dictionary of Idioms. / Ed. by J. Siefring. 2nd ed. Oxford, New York: OUP.

10. Zingarelli, N. (2014) Vocabolario della Lingua Italiana. Milano: Zanichelli.

\section{furhung unupptip $u_{2}$ ulynujpilipnud.}

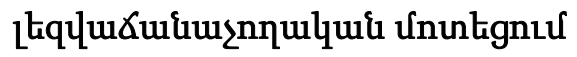

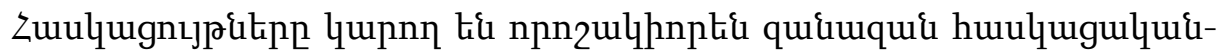

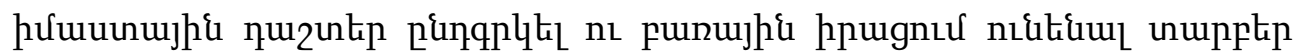

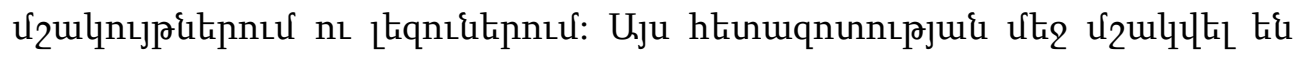

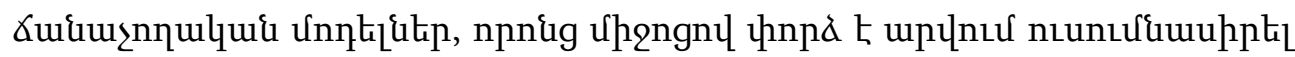

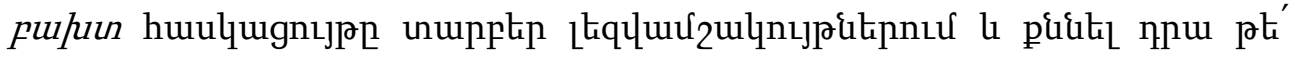

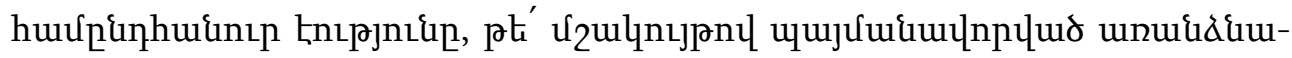

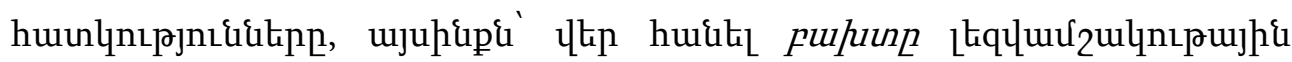

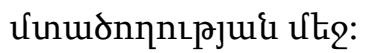

Received by the Editorial Board 01.03.2019

Recommended for publication by the reviewers 03.04.2019

Accepted for print 22.04.2019 